\title{
Morpho-molecular diversity of Linocarpaceae (Chaetosphaeriales): Claviformispora gen. nov. from decaying branches of Phyllostachys heteroclada
}

\author{
Xiu-Lan Xu ${ }^{1,2,3}$, Chun-Lin Yang ${ }^{2,3}$, Rajesh Jeewon ${ }^{4}$, \\ Dhanushka N. Wanasinghe ${ }^{5}$, Ying-Gao Liu ${ }^{2,3}$, Qian-Gang Xiao'
}

I Research Institute of Forestry, Chengdu Academy of Agricultural and Forestry Sciences, Nongke Road 200, Chengdu 611130, China 2 National Forestry and Grassland Administration Key Laboratory of Forest Resources Conservation and Ecological Safety on the Upper Reaches of the Yangtze River, Sichuan Agricultural University, Wenjiang District, Huiming Road 211, Chengdu 611130, China 3 Sichuan Province Key Laboratory of Ecological Forestry Engineering on the Upper Reaches of the Yangtze River, Sichuan Agricultural University, Wenjiang District, Huiming Road 211, Chengdu 611130, China 4 Department of Health Sciences, Faculty of Science, University of Mauritius, Reduit, Mauritius 5 Key Laboratory for Plant Diversity and Biogeography of East Asia, Kunming Institute of Botany, Chinese Academy of Science, Kunming 650201, Yunnan, China

Corresponding author: Xiu-Lan Xu (xuxiulanxxl@126.com); Chun-Lin Yang (yangcl0121@163.com)

Academic editor: N. Wijayawardene | Received 13 May 2020 | Accepted 14 June 2020 | Published 16 July 2020

Citation: Xu X-L, Yang C-L, Jeewon R, Wanasinghe DN, Liu Y-G, Xiao Q-G (2020) Morpho-molecular diversity of Linocarpaceae (Chaetosphaeriales): Claviformispora gen. nov. from decaying branches of Phyllostachys heteroclada. MycoKeys 70: 1-17. https://doi.org/10.3897/mycokeys.70.54231

\begin{abstract}
In this paper, Claviformispora gen. nov. in Linocarpaceae is introduced from Phyllostachys heteroclada in Sichuan Province, China. The new genus is characterised by its distinct morphological characters, such as ostiole with periphyses, asci with a thick doughnut-shaped, J- apical ring and clavate ascospore without septum-like band and appendage. Maximum Likelihood and Bayesian Inference phylogenetic analyses, based on DNA sequence data from ITS, LSU, SSU and TEF- $1 \alpha$ regions, provide further evidence that the fungus is a distinct genus within this family. The new genus is compared with similar genera, such as Linocarpon and Neolinocarpon. Descriptions, illustrations and notes are provided for the new taxon.
\end{abstract}

\section{Keywords}

bambusicolous fungi, one new genus and species, phylogeny, taxonomy

Copyright Xiu-Lan Xu et al. This is an open access article distributed under the terms of the Creative Commons Attribution License (CC BY 4.0), which permits unrestricted use, distribution, and reproduction in any medium, provided the original author and source are credited. 


\section{Introduction}

The order Chaetosphaeriales Huhndorf, A.N. Mill. \& F.A. Fernández (Sordariomycetes) was introduced in Sordariomycetidae O.E. Erikss. \& Winka, based on LSU sequence data (Huhndorf et al. 2004) and currently comprises four families viz. Chaetosphaeriaceae Réblová, M.E. Barr \& Samuels, Helminthosphaeriaceae Samuels, Cand. \& Magni, Leptosporellaceae S. Konta \& K.D. Hyde and Linocarpaceae S. Konta \& K.D. Hyde (Hongsanan et al. 2017; Konta et al. 2017; Wijayawardene et al. 2020). Recently, 43 genera were accepted within Chaetosphaeriaceae and seven genera within Helminthosphaeriaceae (Hyde et al. 2020; Wijayawardene et al. 2020). Based on morphology and combined analyses of ITS and LSU sequence data, Konta et al. (2017) accommodated Linocarpon Syd. \& P. Syd. and Neolinocarpon K.D. Hyde in Linocarpaceae and Leptosporella Penz. \& Sacc. in Leptosporellaceae. Leptosporellaceae and Linocarpaceae are morphologically similar in their dome-shaped ascomata and filiform ascospores (Hyde and Alias 1999; Cai et al. 2004; Konta et al. 2017). The former, however, can be delineated based on ascospores that are narrow, long filiform, with gradually tapering ends and indistinct mucilage (if present), whereas in Linocarpaceae, ascospores have a distinct appendage at the apex and are generally wider and differ in appearance at the ends (Konta et al. 2017).

The genus Leptosporella was introduced with L. gregaria Penz. \& Sacc., 1897 as the type species by Penzig and Saccardo (1897). Lumbsch and Huhndorf (2010) referred it in Sordariomycetidae genera incertae sedis. Subsequently, the genus was referred to the Chaetosphaeriales, based on phylogenetic analysis of LSU sequence data (Huhndorf and Miller 2011; Dai et al. 2016; Wijayawardene et al. 2020). At present, 15 epithets of Leptosporella are recorded in Index Fungorum (http://www.speciesfungorum.org/ Names/Names.asp). Sydow and Sydow (1917) introduced Linocarpon with L. pandani Syd. \& P. Syd., 1917 as the type species. Hyde (1992a) introduced Neolinocarpon to accommodate a linocarpon-like species, N. globosicarpum K.D. Hyde, 1992. Currently in Index Fungorum (2020), 44 and 13 epithets are accommodated in Linocarpon and Neolinocarpon, respectively. Hyde (1997) and Jeewon et al. (2003) reported that Linocarpon and Neolinocarpon can be accommodated in Hyponectriaceae (Xylariales), while Bahl (2006) suggested a closer relationship with Chaetosphaeriales and Xylariales, based on their molecular data. However, with more taxon sampling and fresh collections, Konta et al. (2017) confirmed that Linocarpon and Neolinocarpon should be accommodated in a distinct family (Linocarpaceae) in Chaetosphaeriales.

The present research is a part of our investigations on the taxonomic and phylogenetic circumscriptions of pathogenic and saprobic micro-fungi associated with bamboo in Sichuan Province, China. In this paper, we introduce a new genus Claviformispora in Linocarpaceae, typified by C. phyllostachydis from Phyllostachys heteroclada Oliv., 1894 (Poaceae). The morphological differences and analyses of a combined ITS, LSU, SSU and TEF- $1 \alpha$ sequence dataset support the validity of the new genus and its placement in Linocarpaceae. The new genus is compared with other genera in the family. The comprehensive descriptions and micrographs of new taxa are provided. 


\section{Materials and methods}

\section{Specimen collection and morphological study}

Bamboo materials were collected from Yaan City, China. Single ascospore isolations were carried out following the method described by Chomnunti et al. (2014) and the germinating spores were transferred to PDA, incubated at $25^{\circ} \mathrm{C}$ in the dark and cultural characteristics were determined. Ascomata were observed and photographed using a dissecting microscope NVT-GG (Shanghai Advanced Photoelectric Technology Co. Ltd, China) matched to a VS-800C micro-digital camera (Shenzhen Weishen Times Technology Co. Ltd., China). The anatomical details were visualised using Nikon ECLIPSE $N i$ compound microscope fitted to a Canon 600D digital camera and an OPTEC BK-DM320 microscope matched to a VS-800C micro-digital camera (Shenzhen Weishen Times Technology Co. Ltd., China). Iodine reaction of the ascus wall was tested in Melzer's reagent (MLZ). Lactate cotton blue reagent was used to observe the number of septa. The gelatinous appendage was observed in Black Indian ink. Type specimens were deposited at the Herbarium of Sichuan Agricultural University, Chengdu, China (SICAU) and Mae Fah Luang University Herbarium (MFLU). The ex-type living cultures are deposited at the Culture Collection in Sichuan Agricultural University (SICAUCC) and the Culture Collection at Mae Fah Luang University (MFLUCC). Index Fungorum numbers (http://www.indexfungorum.org/Names/ Names.asp) are registered and provided.

\section{DNA extraction, PCR amplification and DNA sequencing}

Total genomic DNA was extracted from mycelium that were grown on PDA at $25^{\circ} \mathrm{C}$ for two weeks using a Plant Genomic DNA extraction kit (Tiangen, China) following the manufacturer's instructions. The primers pairs LR0R and LR5 (Vilgalys and Hester 1990), NS1 and NS4, ITS5 and ITS4 (White et al. 1990), EF1-983F and EF1-2218R (Rehner 2001) were used for the amplification of the partial large subunit nuclear rDNA (LSU), the partial small subunit nuclear rDNA (SSU), internal transcribed spacers (ITS) and translation elongation factor 1-alpha (TEF-1 $\alpha$ ), respectively.

Polymerase chain reaction (PCR) was performed in $25 \mu$ final volumes containing $22 \mu \mathrm{l}$ of Master Mix (Beijing TsingKe Biotech Co. Ltd.), $1 \mu \mathrm{l}$ of DNA template, $1 \mu \mathrm{l}$ of each forward and reverse primers $(10 \mu \mathrm{M})$. The PCR thermal cycle programmes for LSU, SSU, ITS and TEF1- $\alpha$ gene were amplified as: initial denaturation $94^{\circ} \mathrm{C}$ for 3 minutes, followed by 35 cycles of denaturation at $94{ }^{\circ} \mathrm{C}$ for 30 seconds, annealing at $55^{\circ} \mathrm{C}$ for 50 seconds, elongation at $72{ }^{\circ} \mathrm{C}$ for 1 minute and final extension at $72{ }^{\circ} \mathrm{C}$ for 10 minutes. PCR products were sequenced with the above-mentioned primers at TsingKe Biological Technology Co. Ltd, Chengdu, China. The newly-generated sequences from the LSU, SSU, TEF- $1 \alpha$ and ITS regions were deposited in GenBank (Table 1). 
Table I. Molecular data used in this study and GenBank accession numbers.

\begin{tabular}{|c|c|c|c|c|c|}
\hline \multirow[t]{2}{*}{ Species name } & \multirow[t]{2}{*}{ Strain } & \multicolumn{4}{|c|}{ GenBank accession number } \\
\hline & & LSU & ITS & SSU & TEF \\
\hline Chloridium aquaticum & MFLUCC 11-0212 & MH476567 & MH476570 & MH476573 & - \\
\hline Chloridium aseptatum & MFLUCC 11-0216 & MH476568 & NR_158365 & MH476574 & - \\
\hline Claviformispora phyllostachydis & SICAUCC 16-0004 & MT232720 & MT232736 & MT232735 & MT240855 \\
\hline Cryptophiale hamulata & MFLUCC 18-0098 & MG386756 & - & MG386757 & - \\
\hline \multirow[t]{2}{*}{ Cryptophiale udagawae } & MFLUCC 18-0422 & MH758211 & MH758198 & MH758205 & - \\
\hline & MFLUCC 18-0428 & MH758210 & MH758197 & MH758204 & - \\
\hline Dictyochaeta siamensis & MFLUCC 15-0614 & KX609952 & KX609955 & - & - \\
\hline Dictyochaeta assamica & CBS 242.66 & MH870426 & MH858788 & - & - \\
\hline Dictyochaeta pandanicola & MFLUCC 17-0563 & MH376710 & MH388338 & MH388307 & MH388373 \\
\hline Dictyochaeta terminalis & GZCC 18-0085 & MN104624 & MN104613 & MN104633 & - \\
\hline \multirow[t]{2}{*}{ Echinosphaeria canescens } & SMH4666 & KF765605 & - & - & - \\
\hline & SMH4791 & AY436403 & - & - & - \\
\hline Endophragmiella dimorphospora & FMR_12150 & KY853502 & KY853442 & HF937351 & - \\
\hline Gelasinospora tetrasperma & CBS 178.33 & DQ470980 & NR_077163 & DQ471032 & DQ471103 \\
\hline Helminthosphaeria clavariarum & SMH4609 & AY346283 & - & - & - \\
\hline Hilberina caudata & SMH1542 & KF765615 & - & - & - \\
\hline Infundibulomyces cupulata & BCC11929 & EF113979 & EF113976 & EF113982 & - \\
\hline Infundibulomyces oblongisporus & BCC 13400 & EF113980 & EF113977 & EF113983 & - \\
\hline Kionochaeta castaneae & GZCC 18-0025 & MN104621 & MN104610 & MN104630 & - \\
\hline Kionochaeta microspora & GZCC 18-0036 & MN104618 & MN104607 & MN104627 & - \\
\hline Leptosporella arengae & MFLUCC 15-0330 & MG272246 & MG272255 & MG366594 & MG272259 \\
\hline Leptosporella bambusae & MFLUCC 12-0846 & KU863122 & KU940134 & - & - \\
\hline Leptosporella cocois & MFLUCC 15-0816 & - & MG272256 & - & - \\
\hline \multirow[t]{2}{*}{ Leptosporella gregaria } & SMH4290 & AY346290 & - & - & - \\
\hline & SMH4673 & HM171287 & - & - & - \\
\hline Leptosporella elaeidis & MFLU 19-0669 & MK659772 & MK659767 & MK659774 & MN883560 \\
\hline Linocarpon arengae & MFLUCC 15-0331 & MG272247 & - & MG366596 & - \\
\hline Linocarpon cocois & MFLUCC 15-0812 & MG272248 & MG272257 & MG272253 & - \\
\hline \multirow[t]{2}{*}{ Menispora tortuosa } & DAOM 231154 & AY544682 & KT225527 & AY544723 & - \\
\hline & CBS 214.56 & AF178558 & AF178558 & - & - \\
\hline Menisporopsis anisospora & CBS 109475 & MH874421 & MH862827 & - & - \\
\hline Menisporopsis breviseta & GZCC 18-0071 & MN104623 & MN104612 & MN104632 & - \\
\hline Menisporopsis dushanensis & GZCC 18-0084 & MN104626 & MN104615 & MN104635 & - \\
\hline Menisporopsis pandanicola & KUMCC 17-0271 & MH376726 & MH388353 & MH388320 & MH388388 \\
\hline Menisporopsis theobromae & MFLUCC 15-0055 & KX609954 & KX609957 & - & - \\
\hline Neolinocarpon arengae & MFLUCC 15-0323 & MG272249 & MG272258 & MG366597 & - \\
\hline \multirow[t]{3}{*}{ Neolinocarpon rachidis } & MFLUCC 15-0332 & MG272250 & - & MG366598 & - \\
\hline & MFLUCC 15-0814a & MK106353 & MK106342 & MK106367 & - \\
\hline & MFLUCC 15-0814b & MK106354 & - & MK106368 & \\
\hline \multirow[t]{3}{*}{ Neolinocarpon phayaoense } & MFLUCC 17-0073a & MG581933 & - & MG581936 & MG739512 \\
\hline & MFLUCC 17-0073b & MG581934 & - & MG581937 & MG739513 \\
\hline & MFLUCC 17-0074 & MG581935 & - & MG581938 & MG739514 \\
\hline \multirow[t]{2}{*}{ Phialosporostilbe scutiformis } & MFLUCC 17-0227 & MH758207 & MH758194 & MH758201 & - \\
\hline & MFLUCC 18-1288 & MH758212 & MH758199 & - & - \\
\hline \multirow[t]{2}{*}{ Ruzenia spermoides } & SMH4606 & AY436422 & - & - & - \\
\hline & SMH4655 & KF765619 & - & - & - \\
\hline \multirow[t]{2}{*}{ Synaptospora plumbea } & ANM963 & KF765620 & - & - & - \\
\hline & SMH3962 & KF765621 & - & - & - \\
\hline Sordaria fimicola & CBS 508.50 & MH868251 & MH856730 & - & - \\
\hline \multirow[t]{2}{*}{ Zanclospora iberica } & FMR 11584 & KY853544 & KY853480 & HF937360 & - \\
\hline & FMR 12186 & KY853545 & KY853481 & HF937361 & - \\
\hline
\end{tabular}

Notes. New species in this study is in bold. "-" means that the sequence is missing or unavailable.

Abbreviations. ANM: Collection of A.N. Miller; BCC: BIOTEC Culture Collection, National Center for Genetic Engineering and Biotechnology (BIOTEC), Bangkok, Thailand; CBS: Centraalbureau voor Schimmelcultures, Utrecht, Netherlands; DAOM: Canadian Collection of Fungal Cultures, Agriculture and Agri-Food Canada, Ottawa, Canada; FMR: Facultad de Medicina, Universitat Rovira i Virgili, Reus, Tarragona, Spain; GZCC: Guizhou Culture Collection, Guiyang, China; KUMCC: Kunming Institute of Botany Culture Collection, Chinese Academy of Sciences, Kunming, China; MFLU: Herbarium of Mae Fah Luang University, Chiang Rai, Thailand; MFLUCC: Mae Fah Luang University Culture Collection, Chiang Rai, Thailand; SICAUCC: Sichuan Agricultural University Culture Collection, Sichuan, China; SMH: Collection of S.M. Huhndorf, 


\section{Phylogenetic analyses}

Taxa to be used for phylogenetic analyses were selected, based on results generated from nucleotide BLAST searches online in GenBank and recent publications (Lu et al. 2016; Konta et al. 2017; Senwanna et al. 2018; Wei et al. 2018; Lin et al. 2019). Gelasinospora tetrasperma (CBS 178.33) and Sordaria fimicola (CBS 508.50) were selected as the outgroup taxa. The sequences were downloaded from GenBank (http:// www.ncbi.nlm.nih.gov/) and the accession numbers are listed in Table 1. A combined ITS, LSU, SSU and TEF- $1 \alpha$ sequence dataset was used to construct the phylogenetic tree. DNA alignments were performed by using MAFFT v.7.429 online service (Katoh et al. 2019) and ambiguous regions were excluded with BioEdit version 7.0.5.3 (Hall 1999). Multigene sequences were concatenated by using Mesquite software (Maddison and Maddison 2019). Maximum Likelihood (ML) and Bayesian Inference (BI) analyses were performed. The best nucleotide substitution model was determined by MrModeltest v. 2.2 (Nylander 2004).

Maximum Likelihood analysis and Bayesian Inference analysis were generated by using the CIPRES Science Gateway web server (Miller 2010). RAxML-HPC2 on XSEDE (8.2.10) (Stamatakis 2014) with GTR+GAMMA substitution model with 1000 bootstrap iterations was chosen for Maximum Likelihood analysis. For BI analyses, the best-fit model GTR $+\mathrm{I}+\mathrm{G}$ for ITS, LSU and SSU was selected in MrModeltest 2.2 and $G T R+G$ for TEF. The analyses were computed with six simultaneous Markov Chain Monte Carlo (MCMC) Chains with 8,000,000 generations and a sampling frequency of 100 generations. The burn-in fraction was set to 0.25 and the run automatically ended when the average standard deviation of split frequencies reached below 0.01 .

Phylogenetic trees were visualised with FigTree v.1.4.3 (Rambaut and Drummond 2016) and edited using Adobe Illustrator CS6 (Adobe Systems Inc., United States). Maximum Likelihood bootstrap values (MLBP) equal to or greater than $70 \%$ and Bayesian Posterior Probabilities (BYPP) equal to or greater than 0.95 were accepted. The finalised alignment and tree were deposited in TreeBASE (http://www.treebase. org), submission ID: 25996. The new taxa introduced follow the recommendations of Jeewon and Hyde (2016).

\section{Results}

\section{Phylogenetic analyses}

Phylogenetic analyses of a combined dataset (ITS, LSU, SSU, TEF- $1 \alpha$ ) comprises 51 taxa within the order Chaetosphaeriales (Table 1), including 24 taxa in family Chaetosphaeriaceae, nine taxa in Helminthosphaeriaceae, ten taxa in Linocarpaceae, six taxa in Leptosporellaceae and two outgroup taxa in Sordariales. The dataset consisted of 5,849 characters including gaps $(\mathrm{LSU}=1,571, \mathrm{ITS}=736, \mathrm{SSU}=2,522, \mathrm{TEF}=1,020)$. The best scoring tree of RAxML analysis is shown in Fig. 1, with the support values of ML and BI analyses. 


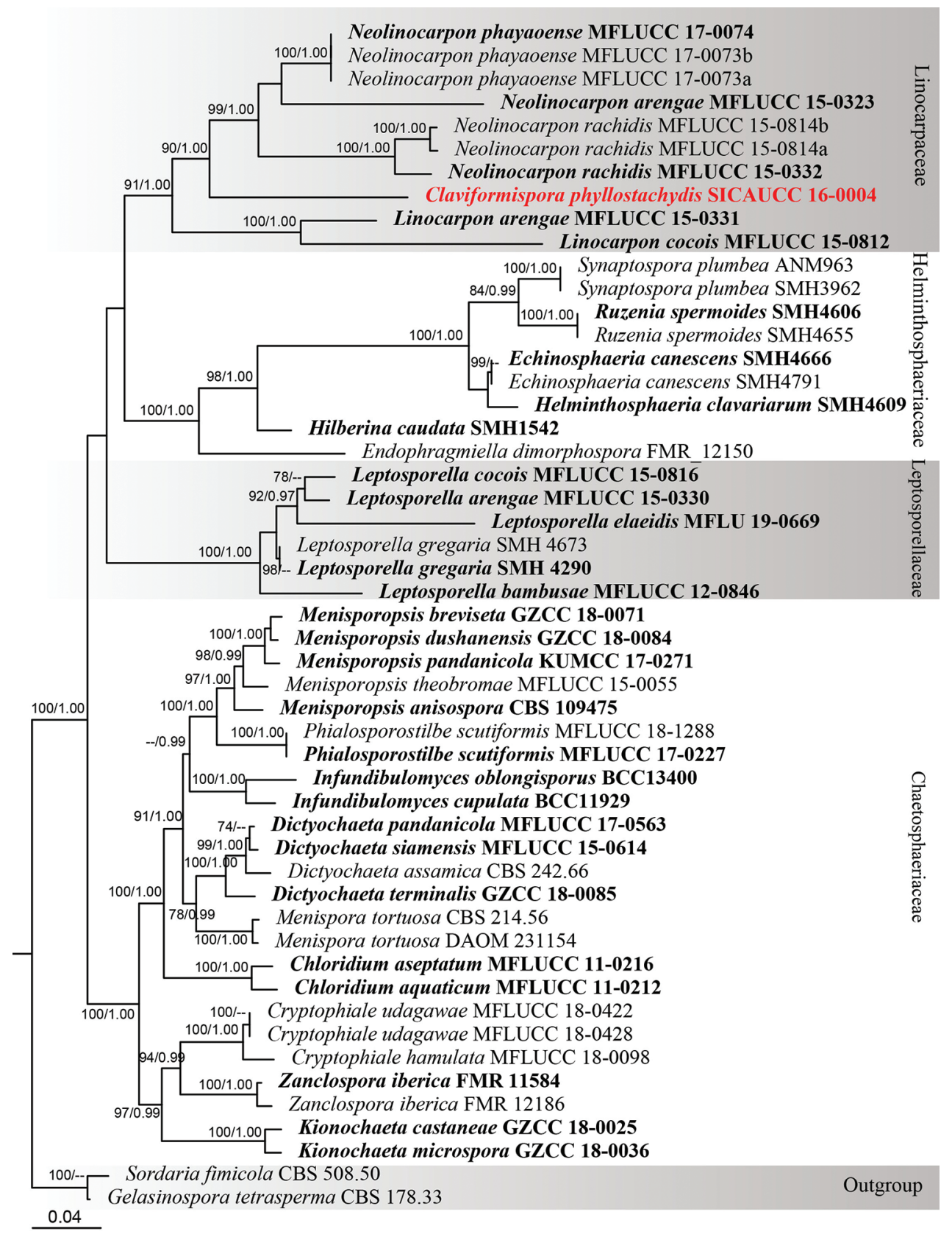

Figure I. Phylogram of RAxML analysis based on a combined ITS, LSU, SSU and TEF- $1 \alpha$ sequence dataset within order Chaetosphaeriales. Bootstrap support values for maximum likelihood (ML, left) greater than $70 \%$ and Bayesian posterior probabilities (PP, right) equal to or greater than 0.95 are indicated at the nodes. The tree is rooted to Gelasinospora tetrasperma (CBS 178.33) and Sordaria fimicola (CBS 508.50). All sequences from ex-type strains are in bold. The newly-generated sequence is in red. 
The best scoring RAxML tree with the final optimisation had a likelihood value of $-26,415.700648$. The matrix had 1,751 distinct alignment patterns and $64.64 \%$ in this alignment is the gaps and completely undetermined characters. Estimated base frequencies were as follows: $\mathrm{A}=0.236065, \mathrm{C}=0.261532, \mathrm{G}=0.295313, \mathrm{~T}=0.207091$, with substitution rates $\mathrm{AC}=1.062535, \mathrm{AG}=1.855434, \mathrm{AT}=0.940219, \mathrm{CG}=1.052604$, $\mathrm{CT}=4.590285, \mathrm{GT}=1.000000$. The gamma distribution shape parameter $\alpha=0.311923$ and the Tree-Length $=2.281738$. The Bayesian analysis resulted in 20,502 trees after $8,000,000$ generations. The first $25 \%$ of trees (1,624 trees), which represent the burnin phase of the analyses were discarded, while the remaining 4,878 trees were used for calculating posterior probabilities. Bayesian posterior probabilities were evaluated by MCMC with a final average standard deviation of split frequencies $=0.009877$.

Phylogenetic trees generated from Maximum Likelihood (ML) and Bayesian Inference analyses were similar in overall topologies. Phylogeny from the combined sequence data analysis indicates that all families were monophyletic with strong bootstrap support values (Fig. 1). Phylogenetic results show that our novel species Claviformispora phyllostachydis (SICAUCC 16-0004) belongs to family Linocarpaceae with 91\% ML and 1.00 BYPP support and close to genera Neolinocarpon and Linocarpon (Fig. 1). The new genus Claviformispora constituted a distinct lineage in the family Linocarpaceae (Fig. 1).

\section{Taxonomy}

Linocarpaceae S. Konta \& K.D. Hyde, Mycosphere 8(10): 1962 (2017) emend.

Type genus. Linocarpon Syd. \& P. Syd.

Description. Saprobic and endophytic fungi on monocotyledons and rarely dicotyledons. Sexual morph: Ascomata solitary or aggregated, superficial or immersed comprising black, dome-shaped or subglobose, slightly raised blistering areas with a central ostiole or immersed with a black shiny papilla. Peridium composed of dark brown to black cells of textura angularis. Hamathecium comprising septate paraphyses that are longer than asci, wider at the base, tapering towards the apex. Asci 8-spored, unitunicate, cylindrical, with a J-, apical ring, developing from the base and periphery of the ascomata. Ascospores parallel or spiral in asci, hyaline or pale yellowish in mass, filiform or claviform, straight or curved, unicellular with or without refringent bands, with or without polar appendages. Asexual morph: Phialophora-like spp. were found in Linocarpon appendiculatum and L. elaeidis cultures (Hyde 1992b), but no records are available for other species.

Notes. Linocarpaceae was introduced as a new family to accommodate Linocarpon and Neolinocarpon species, based on morphology and phylogeny (Konta et al. 2017). Appressoria were first recorded from Neolinocarpon rachidis (Hyde et al. 2019). The new genus Claviformispora, which is well-supported within Linocarpaceae suggests 
that there is a need to amend the morphological circumscriptions of the family given that the ascomata (subglobose) and ascospore (claviform) characters are so different from the other two genera.

\section{Claviformispora X. L. Xu \& C. L. Yang, gen. nov.}

Index Fungorum identifier: IF557395

Type species. Claviformispora phyllostachydis X. L. Xu \& C. L. Yang

Etymology. Name reflects the claviform ascospores.

Description. Saprobic on dead branches. Sexual morph: Stromata solitary or gregarious, black, erumpent. Ascomata solitary or aggregated, immersed, subglobose, slightly raised blistering areas with a central ostiole with periphyses. Peridium outer cells merging with the host tissues, composed of pale to dark brown cells of textura angularis. Hamathecium comprising hyaline, septate paraphyses, longer than asci, wider at the base, tapering towards the apex. Asci 8-spored, cylindrical to cylindric-clavate, unitunicate, short pedicellate, apically rounded, with a doughnut-shaped, refractive, J- apical ring. Ascospores overlapping uniseriate or 2-seriate, clavated with a thin pedicellate, 1-celled, hyaline, without appendage and refringent bands, smooth-walled. Asexual morph: Undetermined.

Notes. Claviformispora resembles Neolinocarpon in having immersed ascomata and ostiole with periphyses, but differs in forming aggregated ascomata, cylindric-clavate, short pedicellate asci, clavate ascospores with thin pedicel and without septa-like bands and appendages, whereas the ascospores of Neolinocarpon and Linocarpon (Linocarpaceae) species are usually filiform with refringent bands and appendages (Hyde 1992b, 1997; Konta et al. 2017). The nature of the ascospore appendages appears to be phylogenetically significant for intergeneric delineation as has been seen in other studies (Poonyth et al. 2000; Jeewon et al; 2003, Thongkantha et al. 2003; Cai et al. 2004; Konta et al. 2017), but this warrants further investigations with more sampling and fresh collections of Neolinocarpon and Linocarpon. Differences in morphology between these genera in Linocarpaceae are summarised in Table 2.

\section{Claviformispora phyllostachydis X. L. Xu \& C. L. Yang, sp. nov.}

Index Fungorum identifier: IF557396

Fig. 2

Type. China, Sichuan Province, Yảan City, Yucheng Distinct, Kongping Township, alt. $1133 \mathrm{~m}, 29^{\circ} 50.14^{\prime} \mathrm{N}, 103^{\circ} 03^{\prime} \mathrm{E}$, on dead branches of Phyllostachys heteroclada Oliv. (Poaceae), 11 December 2016, C. L. Yang and X. L. Xu, YCL201612002 (SICAU 16-0007, holotype; MFLU 18-1217, isotype), ex-type living culture, SICAUCC 160004 = MFLUCC 18-1230.

Etymology. The specific epithet refers to the host genus Phyllostachys.

Description. Saprobic on dead branches of Phyllostachys heteroclada Oliv. Sexual morph: Stromata solitary comprising elliptical areas or aggregated in large black 
Table 2. Morphological comparison of Linocarpon, Neolinocarpon and Claviformispora.

\begin{tabular}{|c|c|c|c|}
\hline \multirow[t]{2}{*}{ Morphology } & Linocarpon & Neolinocarpon & Claviformispora \\
\hline & (Type: L.pandani) & (Type: $N$. globosicarpum) & (Type: C.phyllostachydis) \\
\hline Stromata & Absent & Absent & $\begin{array}{l}\text { Solitary or aggregated, comprising } \\
\text { elliptical areas and large black areas, with } \\
\text { slit-like openings }\end{array}$ \\
\hline Ascomata & $\begin{array}{l}\text { Solitary, superficial, subglobose, } \\
\text { comprising black, dome-shaped, raised } \\
\text { blistering areas, central ostiole }\end{array}$ & $\begin{array}{l}\text { Solitary, deeply immersed, oval to } \\
\text { globose, with central raised, dark, shiny } \\
\text { papilla, central ostiole with periphyses }\end{array}$ & $\begin{array}{l}\text { Solitary or aggregated, deeply immersed, } \\
\text { subglobose, slightly raised blistering } \\
\text { areas, central ostiole with periphyses }\end{array}$ \\
\hline Peridium & Textura angularis & Textura angularis & Textura angularis \\
\hline Hamathecium & $\begin{array}{l}\text { Hyaline, septate paraphyses, longer } \\
\text { than asci }\end{array}$ & $\begin{array}{c}\text { Hyaline, septate paraphyses, longer } \\
\text { than asci }\end{array}$ & $\begin{array}{c}\text { Hyaline, septate paraphyses, longer } \\
\text { than asci }\end{array}$ \\
\hline Asci & $\begin{array}{l}\text { Cylindrical, unitunicate, a small non- } \\
\text { amyloid apical ring }\end{array}$ & $\begin{array}{l}\text { Long cylindrical, pedicellate, } \\
\text { unitunicate, an oblong to wedge-shaped, } \\
\text { refractive, apical ring and some with a } \\
\text { refractive circular body below }\end{array}$ & $\begin{array}{l}\text { Cylindrical to cylindric-clavate, } \\
\text { unitunicate, pedicellate, doughnut- } \\
\text { shaped, refractive, J-apical ring }\end{array}$ \\
\hline Ascospores & $\begin{array}{l}\text { Filiform, aseptate, hyaline or pale- } \\
\text { yellowish in mass, parallel or spiral, with } \\
\text { appendage and refringent septum-like } \\
\text { bands or absent }\end{array}$ & $\begin{array}{c}\text { Filiform, aseptate, hyaline or pale- } \\
\text { yellowish in mass, parallel or spiral, with } \\
\text { apical appendages and refringent bands } \\
\text { or absent }\end{array}$ & $\begin{array}{l}\text { Clavate, thin pedicellate, aseptate, } \\
\text { hyaline, parallel, no appendage and } \\
\text { refringent band }\end{array}$ \\
\hline Asexual morph & $\begin{array}{l}\text { Only found in L. appendiculatum and } \\
\text { L. elaeidis, conidiophore arising from } \\
\text { the aerial mycelium, conidiogenous cells } \\
\text { phialidic, smooth, translucent brown, } \\
\text { conidia clavate to fusiform, straight } \\
\text { or slightly curved or slightly sinuous, } \\
\text { unicellular, smooth, colourless }\end{array}$ & Undetermined & Undetermined \\
\hline Others & $\begin{array}{l}\text { Colonies on MEA and PDA growing } \\
\text { slowly }\end{array}$ & $\begin{array}{l}\text { Colonies on MEA growing slowly. } \\
\text { Ascospores on MEA produced } \\
\text { appressoria-like structures at each tip of } \\
\text { germ tube, only found in } N \text {. rachidis }\end{array}$ & Colonies on PDA grow faster \\
\hline References & $\begin{array}{l}\text { Hyde (1992b), Konta et al. (2017), } \\
\text { Thongkantha et al. (2003) }\end{array}$ & $\begin{array}{l}\text { Hyde et al. (2019), Senwanna et al. } \\
\text { (2018), Hyde et al. (1998) }\end{array}$ & This study \\
\hline
\end{tabular}

areas, slightly raised with slit-like openings presenting on host surface. Ascomata $120-240 \mu \mathrm{m}$ high $\times 220-490 \mu \mathrm{m}$ diameter $(\bar{x}=189 \times 345 \mu \mathrm{m}, \mathrm{n}=20)$, perithecial, immersed, central, papillate ostiole with periphyses, oval-globose in section, the cells between the perithecia are composed with tissue of stromata and host. Peridium 20-40 $\mu \mathrm{m}$ wide $(\bar{x}=33 \mu \mathrm{m}, \mathrm{n}=10)$, outer cells merging with the host tissues, composed of pale to dark brown cells of textura angularis. Hamathecium comprising hyaline, hypha-like, septate paraphyses, occasionally branched, longer than asci, wider at the base, $2-4 \mu \mathrm{m}$ diameter $(\bar{x}=2.7 \mu \mathrm{m}, \mathrm{n}=20)$ tapering towards the apex, $0.78-$ $1.20 \mu \mathrm{m}$ diameter $(\bar{x}=0.98 \mu \mathrm{m}, \mathrm{n}=20)$. Asci $90-160 \times 9-15 \mu \mathrm{m}(\bar{x}=118 \times 13 \mu \mathrm{m}$, $\mathrm{n}=20$ ), 8 -spored, cylindrical to cylindric-clavate, unitunicate, short pedicellate, apically rounded, with a massive, doughnut-shaped, refractive, J- reaction, apical ring. Ascospores 35-50 × 5.7-8.6 $\mu \mathrm{m}(\bar{x}=45.7 \times 7.0 \mu \mathrm{m}, \mathrm{n}=40)$, overlapping uniseriate or 2-seriate, claviform typically with a thin pedicel, aseptate, hyaline, straight or slight curved, without appendage and septum-like bands, guttulate when maturity. Asexual morph: Undetermined.

Culture characters. Ascospores germinated on PDA within 12 hours at both ends. Colonies on PDA reaching $5 \mathrm{~cm}$ diameter after 7 days at $25^{\circ} \mathrm{C}$, white to grey with strong radiations outwards on forward side. Colonies became dark brown and black on the reverse after a long time of cultivation. The hyphae are septate, branched, smooth. 

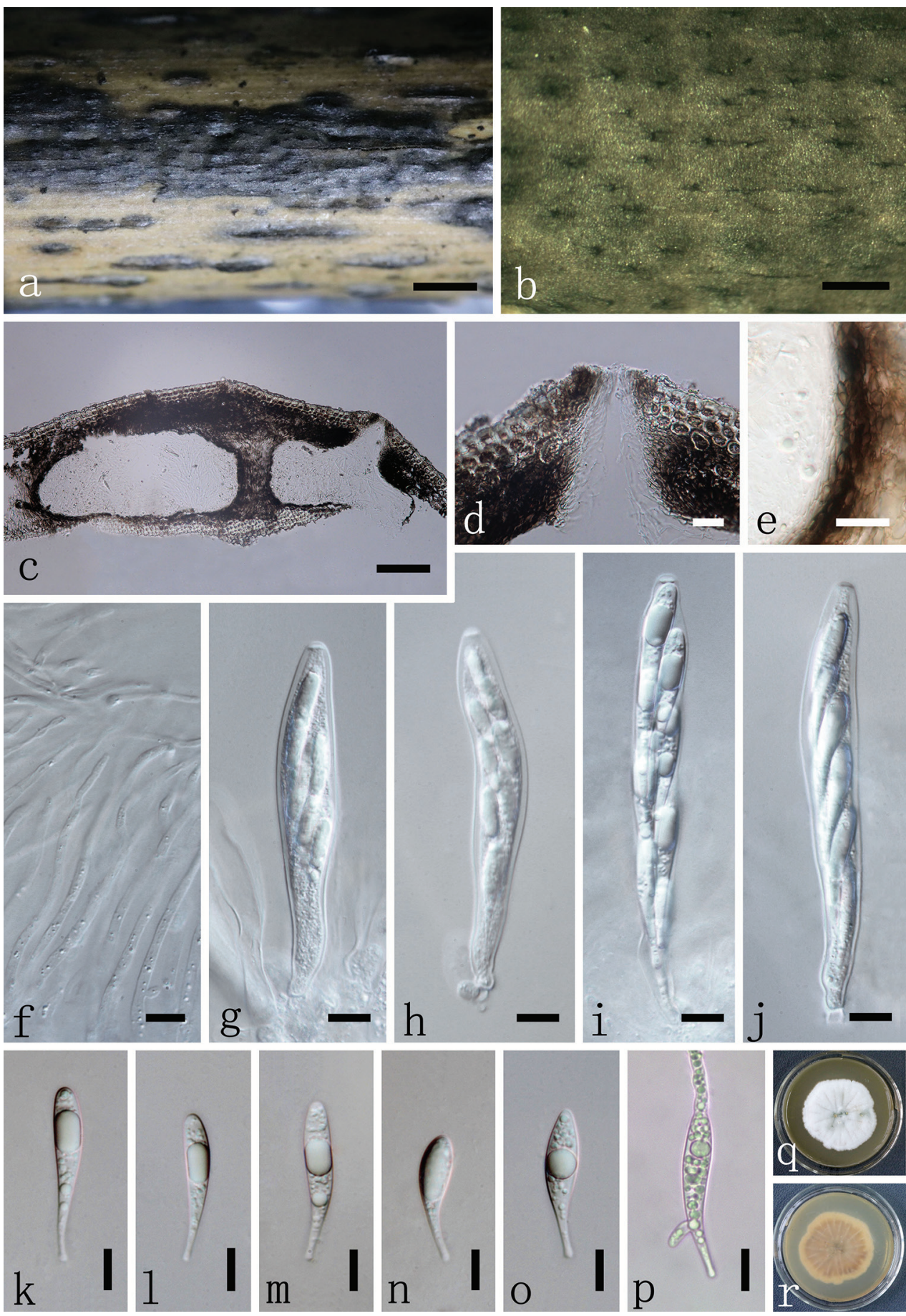

Figure 2. Claviformispora phyllostachydis (SICAU 16-0007, holotype) a, b Stromata on host substrate $\mathbf{c}$ section through ascoma with ascomata $\mathbf{d}$ ostiole with periphyses $\mathbf{e}$ peridium $\mathbf{f}$ paraphyses $\mathbf{g}-\mathbf{j}$ asci $\mathbf{k}-\mathbf{o}$ ascospores $\mathbf{p}$ germinated ascospore $\mathbf{q}, \mathbf{r}$ colony on PDA after 7 days. Scale bars: $2 \mathrm{~mm}(\mathbf{a}), 500 \mu \mathrm{m}(\mathbf{b})$, $100 \mu \mathrm{m}(\mathbf{c}), 20 \mu \mathrm{m}(\mathbf{d}, \mathbf{e}), 10 \mu \mathrm{m}(\mathbf{f}-\mathbf{p})$. 


\section{Discussion}

This study establishes a new genus and also provides further insights into the phylogeny of members associated with Linocarpaceae. Morphologically-based examinations of Claviformispora (as discussed above) clearly show that the morphological circumscriptions (familial concept) of species should be broadened and possibly indicate that this family is much more diverse than expected. Our collection can be clearly distinguished from other groups of similar fungi in Linocarpaceae with its interesting ascospore morphology. In addition, we also noted some peculiarities in the DNA sequences we analysed. A comparison of ITS sequences, based on BLAST reveals 34\%, 26\% and 30\% base pair differences with L. cocois (MFLUCC 15-0812), $N$. arengae (MFLUCC 15-0323) and $N$. rachidis (MFLUCC 15-0814a), respectively. There are more than 9\% and 5\% sequence differences with the three taxa when the LSU and SSU rDNA sequences were compared respectively. Following the guidelines recommended by Jeewon and Hyde (2016), there are therefore sufficient grounds to establish a new species at the genus rank.

Species of Linocarpaceae have been found on Arecaceae, Poaceae, Euphorbiaceae, Zingiberaceae, Pandanaceae, Fagaceae, Fabaceae and Smilacaceae, including Arenga, Attalea, Calamus, Trachycarpus, Acrocomia, Archontophoenix, Cocos, Daemonorops, Licuala, Livistona, Plectocomia, Phoenix, Raphia, Sabal, Mauritia, Nypa, Elaeis, Pinanga, Eugeissona, Pennisetum, Gramineae, Stipa, unidentified bamboo, Hevea, Manihot, Alpinia, Pandanus, Quenrcus, Cajanus and Smilax (Hyde 1988, 1992a, b; Dulymamode et al. 1998; Hyde et al. 1998; Hyde and Alias 1999; Thongkantha et al. 2003; Cai et al. 2004; Bhilabutra et al. 2006; Vitoria et al. 2013; Konta et al. 2017; Senwanna et al. 2018). More than $50 \%$ of the species were recorded from hosts of the Arecaceae. Species in Linocarpaceae are mostly saprobic, except Linocarpon palmetto which was discovered as a pathogen of Sabal palmetto in Florida (Barr 1978). Four species in Linocarpaceae from Poaceae have been reported so far, including Neolinocarpon penniseti on Pennisetum purpureum (Bhilabutra et al. 2006), Linocarpon williamsii on Gramineae sp. (Hansford 1954), L. stipae on Stipa sp. (Hansford 1954) and L. bambusicola on unidentified bamboo submerged in a river (Cai et al. 2004).

Phyllostachys heteroclada, mainly a food source and use as a material in the weaving industry, is distributed along the Yellow River Valley and the southern Provinces in China. It is common in the mountainous areas of Sichuan Province with distribution up to 1,500 $\mathrm{m}$ above sea level (Yi 1997; Yi et al. 2008). There is a large area of pure forest in Yibin, Leshan and Yàn Cities and sporadic distribution in other areas. According to preliminary statistics, bambusicolous fungi from seven orders (excluding fungi referred to as Sordariomycetes incertae sedis) have been recorded on $P$. heteroclada, including Hypocreales, Ostropales, Pleosporales, Phyllachorales, Pucciniales, Ustilaginales and Xylariales, of which Pleosporales is the largest one. Most bambusicolous fungi in China were recorded with inadequate morphological descriptions or molecular data. The early known fungi on P. heteroclada are documented as Aciculosporium take, Ellisembia pseudoseptata, Fusarium oxysporum, F. semitectum, Phyllachora gracilis, Ph. orbicular, Shiraia bambusicola, Stereostratum corticioides and Ustilago shiraiana (Zhou et al. 2001; Xu et al. 2006). In recent years, some new records and taxa, viz. Bambusicola subthailandica, 
B. sichuanensis, Neostagonosporella sichuanensis, Parakarstenia phyllostachydis, Phyllachora heterocladae, Podonectria sichuanensis, Arthrinium yunnanum and A. phyllostachium have been reported (Yang et al. 2019a, b, c, d, e, f). Here, we introduce a new genus in order Chaetosphaeriales, which is a contribution to fungal diversity on $P$. heteroclada.

\section{Acknowledgements}

We all thank Dr. Shaun Pennycook for his help with the nomenclature of the novel species. Xiu-Lan Xu thanks the Chengdu Science and Technology Bureau for funding her research. Ying-Gao Liu and Chun-Lin Yang acknowledge the "Study on identification of pathogenic fungi and prevention techniques for witches' broom of Phyllostachys violascens" (fund from the Bureau of Economic Information and Science \& Technology of Yucheng District in Ya'an City) for supporting this work. Dhanushka Wanasinghe would like to thank CAS President's International Fellowship Initiative (PIFI) for funding his postdoctoral research (number 2019PC0008) and the National Science Foundation of China and the Chinese Academy of Sciences (grant no.: 41761144055). R Jeewon thanks University of Mauritius for support.

\section{References}

Bahl J (2006) Molecular evolution of three morphologically similar families in the Xylariomycetidae (Apiosporaceae, Clypeosphaeriaceae, Hyponectriaceae). PhD Thesis, The University of Hong Kong, China.

Barr ME (1978) The Diaporthales in North America: with emphasis on Gnomonia and its segregates. Mycologia Memoir 7: 1-232.

Bhilabutra W, Lumyong S, Jeewon R, McKenzie EHC, Hyde KD (2006) Neolinocarpon penniseti sp. nov. on the grass Pennisetum purpureum (Poaceae). Cryptogamie, Mycologie 27(4): 305-310.

Cai L, Zhang KQ, McKenzie EHC, Hyde KD (2004) Linocarpon bambusicola sp. nov. and Dictyochaeta curvispora sp. nov. from bamboo submerged in freshwater. Nova Hedwigia 78(3): 439-445. https://doi.org/10.1127/0029-5035/2004/0078-0439

Chomnunti P, Hongsanan S, Hudson BA, Tian Q, Peršoh D, Dhami MK, Alias AS, Xu J, Liu X, Stadler M, Hyde KD (2014) The sooty moulds. Fungal Diversity 66(1): 1-36. https://doi. org/10.1007/s13225-014-0278-5

Dai DQ, Phookamsak R, Wijayawardene NN, Li WJ, Bhat DJ, Xu JC, Tayor JE, Hyde KD, Chukeatirote K (2017) Bambusicolous fungi. Fungal Diversity 82(1): 1-105. https://doi. org/10.1007/s13225-016-0367-8

Dulymamode R, Cannon PF, Peerally A (1998) Fungi from Mauritius: Linocarpon species on Pandanus. Mycological Research 102(11): 1331-1337. https://doi.org/10.1017/ S0953756298006406

Hall TA (1999) BioEdit: a user-friendly biological sequence alignment editor and analysis program for Windows 95/98/NT. Nucleic Acids Symposium Series 41: 95-98. 
Hansford CG (1954) Australian Fungi. II. New species and revisions. Proceedings of the Linnean Society of New South Wales 79: 97-141.

Hongsanan S, Maharachchikumbura SSN, Hyde KD, Samarakoon MC, Jeewon R, Zhao Q, Al-sadi AM, Bahkali AH (2017) An updated phylogeny of Sordariomycetes based on phylogenetic and molecular clock evidence. Fungal Diversity 84(1): 25-41. https://doi. org/10.1007/s13225-017-0384-2

Huhndorf SM, Miller AN (2011) A molecular re-appraisal of taxa in the Sordariomycetidae and a new species of Rimaconus from New Zealand. Studies in Mycology 68: 203-210. https://doi.org/10.3114/sim.2011.68.09

Huhndorf SM, Miller AN, Fernández FA (2004) Molecular systematics of the Sordariales: the order and the family Lasiosphaeriaceae redefined. Mycologia 96(2): 368-387. https://doi. org/10.1080/15572536.2005.11832982

Hyde KD (1992a) Fungi from decaying intertidal fronds of Nypa fruticans, including three new genera four new species. Botanical Journal of the Linnean Society 110(2): 95-110. https://doi.org/10.1111/j.1095-8339.1992.tb00284.x

Hyde KD (1992b) Fungi from palms. I. The genus Linocarpon, a revision. Sydowia 44: 32-54. Hyde KD (1997) Additions to the genus Linocarpon (Ascomycetes: Hyponectriaceae). Botanical Journal of theLinnean Society 123(2):109-131. https://doi.org/10.1111/j.1095-8339.1997. tb01407.x

Hyde KD (1988) The genus Linocarpon from the mangrove palm Nypa fruticans. Transactions of the Mycological Society of Japan 29: 339-350.

Hyde KD, Alias SA (1999) Linocarpon angustatum sp. nov., and Neolinocarpon nypicola sp. nov. from petioles of Nypa fruticans, and a list of fungi from aerial parts of this host. Mycoscience 40(2): 145-149. https://doi.org/10.1007/BF02464293

Hyde KD, Norphanphoun C, Maharachchikumbura SSN, Bhat DJ, Jones EBG, Bundhun D, Chen YJ, Bao DF, Boonmee S, Calabon MS, Chaiwan N, Chethana KWT, Dai DQ, Dayarathne MC, Devadatha B, Dissanayake AJ, Dissanayake LS, Doilom M, Dong W, Fan XL, Goonaselara ID, Hongsanan S, Huang SK, Jayawardena RS, Jeewon R, Karunarathna A, Konta S, Kumar V, Lin CG, Liu JK, Liu NG, Luangsa-ard J, Lumyong S, Luo ZL, Marasinghe DS, McMenzie EHC, Niego AGT, Niranjan M, Perera RH, Phukhamsakda C, Rathnayaka AR, Samarakoon MC, Samarakoon SMBC, Sarma VV, Senanayake IC, Shang QJ, Stadler M, Tibpromma S, Wanasinghe DN, Wei DP, Wijayawardene NN, Xiao YP, Yang J, Zeng XY, Zhang SN, Xiang MM (2020) Refined families of Sordariomycetes. Mycosphere 11(1): 305-1059. https://doi.org/10.5943/mycosphere/11/1/7

Hyde KD, Taylor JE, Fröhlich J (1998) Fungi from palms. XXXIV. The genus Neolinocarpon with five new species and one new combination. Fungal Diversity 1: 115-131.

Hyde KD, Tennakoon DS, Jeewon R, Bhat DJ, Maharachchikumbura SSN, Rossi W, Leonardi M, Lee HB, Mum HY, Houbraken J, Nguyen TTT, Jeon SJ, Frisvad JC, Wanasinghe DN, Lücking R, Aptroot A, Cáceres MES, Karunarathna SC, Hongsanan S, Phookamsak R, de Silva NI, Thambugala KM, Jayawardena RS, Senanayake IC, Boonmee S, Chen J, Luo ZL, Phukhamsakda C, Pereira OL, Abreu VP, Rosado AWC, Bart B, Randrianiohany E, Hofstetter V, Gibertoni TB, da Silva Soares AM, Plautz Jr HL, Sotão HMP, Xavier WKS, Bezerra JDP, de Oliveira TGL, de Souza-Motta CM, Magalhães OMC, Bundhun D, Harishchandra D, Manawasinghe IS, Dong W, Zhang SN, Bao DF, Samarakoon MC, 
Pem D, Karunarathna A, Lin CG, Yang J, Perera RH, Kumar V, Huang SK, Dayarathne MC, Ekanayaka AH, Jayasiri SC, Xiao YP, Konta S, Niskanen T, Liimatainen K, Dai YC, Ji XH, Tian XM, Mešić A, Singh SK, Phutthacharoen K, Cai L, Sorvongxay T, Thiyagaraja V, Norphanphoun C, Chaiwan N, Lu YZ, Jiang HB, Zhang JF, Abeywickrama PD, Aluthmuhandiram JVS, Brahmanage RS, Zeng M, Chethana T, Wei DP, Réblová M, Fournier J, Nekvindová J, do Nascimento Barbosa R, dos Santos JEF, de Oliveira NT, Li GJ, Ertz D, Shang QJ, Phillips AJL, Kuo CH, Camporesi E, Bulgakov TS, Lumyong S, Jones EBG, Chomnunti P, Gentekaki E, Bungartz F, Zeng XY, Fryar S, Tkalčec Z, Liang JM, Li GS, Wen TC, Singh PN, Gafforov Y, Promputtha I, Yasanthika E, Goonasekara ID, Zhao RL, Zhao Q, Kirk PM, Liu JK, Yan JY, Mortimer PE, Xu JC, Doilom M (2019) Fungal diversity notes 1036-1150: taxonomic and phylogenetic contributions on genera and species of fungal taxa. Fungal Diversity 96:1-242. https://doi.org/10.1007/s13225-019-00429-2 Index Fungorum (2020) Index Fungorum. http://www.indexfungorum.org/Names/Names.asp [Accessed 4 May 2020]

Jayasiri SC, Hyde KD, Ariyawansa HA, Bhat J, Buyck B, Cai L, Dai YC, Abd-Elsalam KA, Ertz D, Hidayat I, Jeewon R, Jones EBG, Bahkali AH, Karunarathna SC, Liu JK, Luangsa-ard JJ, Lumbsch HT, Maharachchikumbura SSN, McKenzie EHC, Moncalvo JM, GhobadNejhad M, Nilsson H, Pang KL, Pereira O, Phillips AJL, Raspé O, Rollins AW, Romero AI, Etayo J, Selçuk F, Stephenson SL, Suetrong S, Taylor JE, Tsui CKM, Vizzini A, AbdelWahab MA, Wen TC, Boonmee S, Dai DQ, Daranagama DA, Dissanayake AJ, Ekanayaka AH, Fryar SC, Hongsanan S, Jayawardena RS, Li WJ, Perera RH, Phookamsak R, de Silva NI, Thambugala KM, Tian Q, Wijayawardene NN, Zhao RL, Zhao Q, Kang JC, Promputtha I (2015) The Faces of Fungi database: fungal names linked with morphology, phylogeny and human impacts. Fungal Diversity 74(1): 3-18. https://doi.org/10.1007/ s13225-015-0351-8

Jeewon R, Hyde KD (2016) Establishing species boundaries and new taxa among fungi: recommendations to resolve taxonomic ambiguities. Mycosphere 7(11): 1669-1677. https://doi. org/10.5943/mycosphere/7/11/4

Jeewon R, Liew ECY, Hyde KD (2003) Molecular systematics of the Amphisphaeriaceae based on cladistic analyses of partial LSU rDNA gene sequences. Mycological Research 107(12): 1392-1402. https://doi.org/10.1017/S095375620300875X

Jeewon R, Liew ECY, Simpson JA, Hodgkiss IJ, Hyde KD (2003) Phylogenetic significance of morphological characters in the taxonomy of Pestalotiopsis species. Molecular Phylogenetics and Evolution 27(3): 372-383. https://doi.org/10.1016/S1055-7903(03)00010-1

Katoh K, Rozewicki J, Yamada KD (2019) MAFFT online service: multiple sequence alignment, interactive sequence choice and visualization. Briefings in Bioinformatics 20: 11601166. https://doi.org/10.1093/bib/bbx108

Konta S, Hongsanan S, Liu JK, Eungwanichayapant PD, Jeewon, R, Hyde KD, Maharachchikumbura SSN, Boonmee S (2017) Leptosporella (Leptosporellaceae fam. nov.) and Linocarpon and Neolinocarpon (Linocarpaceae fam. nov.) are accommodated in Chaetosphaeriales. Mycosphere 8(10): 1943-1974. https://doi.org/10.5943/mycosphere/8/10/16

Lin CG, McKenzie EHC, Liu JK, Jones EBG, Hyde KD (2019) Hyaline-spored chaetosphaeriaceous hyphomycetes from Thailand and China, with a review of the family Chaetosphaeriaceae. Mycosphere 10(1): 655-700. https://doi.org/10.5943/mycosphere/10/1/14 
Lu YZ, Liu KJ, Hyde KD, Bhat DJ, Xiao YP, Tian Q, Wen TC, Boonmee S, Kang JC (2016) Brunneodinemasporium jonesii and Tainosphaeria jonesii spp. nov. (Chaetosphaeriaceae, Chaetosphaeriales) from southern China. Mycosphere 7(9): 1322-1331. https://doi. org/10.5943/mycosphere/7/9/6

Lumbsch HT, Huhndorf SM (2010) Myconet (Vol. 14). Part One. Outline of Ascomycota-2009. Part Two. Notes on Ascomycete Systematics. Nos. 4751-5113. Fieldina Life and Earth Sciences 1: 1-64. https://doi.org/10.3158/1557.1

Maddison W P, Maddison DR (2019) Mesquite: a modular system for evolutionary analysis. Version 3.61. http://www.mesquiteproject.org

Miller MA, Pfeiffer WT, Schwartz T (2010) Creating the CIPRES Science Gateway for Inference of Large Phylogenetic Tree. Gateway Computing Environments Workshop (GCE), 8 pp. https://doi.org/10.1109/GCE.2010.5676129

Nylander JAA, MrModeltest v2 (2004) Program distributed by the author. https://www.researchgate.net/publication/285805344

Penzig AJO, Saccardo PA (1897) Diagnoses fungorum novorum in Insula Java collectorum. Series. I. Malpighia 11: 387-409. https://doi.org/10.5962/bhl.title.4921

Poonyth AD, Hyde KD, Wong SW, Peerally A (2000) Ultrastructure of asci and ascospore appendages in Linocarpon appendiculatum and L. nypae. Botanica Marina 43(3): 213-221. https://doi.org/10.1515/BOT.2000.023

Rambaut A, Drummond A (2016) FigTree: Tree figure drawing tool, version 1.4.3. http://tree. bio.ed.ac.uk/software/figtree/ [accessed 04 May 2020]

Rehner S (2001) Primers for elongation factor 1- $\alpha$ (EF1- $\alpha$ ). http://ocid.NACSE.ORG/research/deephyphae/EF1primer.pdf [accessed 04 May 2020]

Senwanna C, Phookamsak R, Bahkali AH, Elgorban AM, Cheewangkoon R, Hyde KD (2018) Neolinocarpon phayaoense sp. nov. (Linocarpaceae) from Thailand. Phytotaxa 362(1): 077086. https://doi.org/10.11646/phytotaxa.362.1.6

Stamatakis A (2014) RAxML version 8: a tool for phylogenetic analysis and post-analysis of large phylogenies. Bioinformatics 30(9): 1312-1313. https://doi.org/10.1093/bioinformatics/btu033

Sydow H, Sydow P (1917) Beitrag zur Kenntniss der Pilzflora der Philippinen-Inseln. Annales Mycologici 15: 165-268.

Thongkantha S, Lumyong S, Lumyong P, Whitton SR, McKenzie EHC, Hyde KD (2003) Microfungi on the Pandanaceae: Linocarpon lammiae sp. nov., L. siamensis sp. nov. and $L$. suthepensis sp. nov. are described with a key to Linocarpon species from the Pandanaceae. Mycologia 95(2): 360-367. https://doi.org/10.1080/15572536.2004.11833122

Vilgalys R, Hester M (1990) Rapid genetic identification and mapping of enzymatically amplified ribosomal DNA from several Cryptococcus species. Journal of Bacteriology 172(8): 4238-4246. https://doi.org/10.1128/JB.172.8.4238-4246.1990

Vitoria NS, Cavalcanti MAQ, Santos CDD, Pereira J, Bezerra JL (2013) Neolinocarpon attaleae sp nov on Attalea funifera (Arecaceae) from Brazil. Mycotaxon 123(1): 141-145. https://doi.org/10.5248/123.141

Wei MJ, Zhang H, Dong W, Boonmee S, Zhang D (2018) Introducing Dictyochaeta qauatica sp. nov. and two new species of Chloridium (Chaetosphaeriaceae, Sordariomycetes) from aquatic habitat. Phytotaxa 362(2): 187-199. https://doi.org/10.11646/phytotaxa.362.2.5 
White TJ, Bruns T, Lee S, Taylor J (1990) Amplifcation and direct sequencing of fungal ribosomal RNA genes for phylogenetics. PCR Protocols: A Guide to Methods and Applications 18: 315-322. https://doi.org/10.1016/B978-0-12-372180-8.50042-1

Wijayawardene N, Hyde KD, Al-Ani LKT, Tedersoo L, Haelewaters D, Rajeshkumar KC, Zhao RL, Aptroot A, Leontyev DV, Saxena RK, Tokarev YS, Dai DQ, Letcher PM, Stephenson SL, Ertz D, Lumbsch HT, Kukwa M, Issi IV, Madrid H, Phillips AJL, Selbmann L, Pfliegler WP, Horváth E, Bensch K, Kirk P, Kolaříková Z, Raja HA, Radek R, Papp V, Dima B, Ma J, Malosso E, Takamatsu S, Rambold G, Gannibal PB, Triebel D,Gautam AK, Avasthi S, Suetrong S, Timdal E, Fryar SC, Delgado G, Réblová M, Doilom M, Dolatabadi S, Pawłowska J, Humber RA, Kodsueb R, Sánchez-Castro I, Goto BT, Silva DKA, de Souza FA, Oehl F, da Silva GA, Silva IR, Błaszkowski J, Jobim K, Maia LC, Barbosa FR, Fiuza PO, Divakar PK, Shenov BD, Castañeda-Ruiz RF, Somrithipol S, Karunarathna SC, Tibpromma S, Mortimer PE, Wanasinghe DN, Phookamsak R, Xu JC, Wang Y, Tian FH, Alvarado P, Li DW, Kušan I, Matočec N, Maharachchikumbura SSN, Papizadeh M, Heredia G, Wartchow F, Bakhshi M, Boehm E, Youssef N, Hustad VP, Lawrey JD, de A Santiago ALCM, Tian Q, Houbraken J, Hongsanan S, Tanaka K, Dissanayake AJ, Monteiro JS, Grossart HP, Suija A, Weerakoon G, Etayo J, Tsurykau A, Kuhnert E, Vázquez V, Mungai P, Damm U, Li QR, Zhang H, Boonmee S, Lu YZ, Becerra AG, Kendrick B, Brearley FQ, Motiejūnaitė J, Sharma B, Khare R, Gaikwad S, Wijesundara DSA, Tang LZ, He MQ, Flakus A, Rodriguez-Flakus P, Zhurbenko MP, McKenzie EHC, Stadler M, Bhat DJ, Liu JK, Raza M, Jeewon R, Nassonova ES, Prieto M, Ja yalal RGU, Yurkov A, Schnittler M, Shchepin ON, Novozhilov YK, Liu P, Cavender JC, Kang YQ, Mohammad S, Zhang LF, Xu RF, Li YM, Dayarathne MC, Ekanayaka AH, Wen TC, Deng CY, Lateef AA, Pereira OL, Navathe S, Hawksworth DL, Fan XL, Dissanayake LS, Erdoğdu M (2020) Outline of Fungi and fungi-like taxa. Mycosphere 11(1): 1060-1456. https://doi. org/10.5943/mycosphere/11/1/8

Xu MQ, Dai YC, Fan SH, Jin LX, Lv Q, Tian GZ, Wang LF (2006) Records of bamboo diseases and the taxonomy of their pathogens in China (I). Forest Research 19(6): 692-699. https://doi.org/10.13275/j.cnki.lykxyj.2006.06.004

Yang CL, Baral HO, Xu XL, Liu YG (2019a) Parakarstenia phyllostachydis, a new genus and species of non-lichenized Odontotremataceae (Ostropales, Ascomycota). Mycological Progress 18(6): 833-845. https://doi.org/10.1007/s11557-019-01492-4

Yang CL, Xu XL, Dong W, Wanasinghe DN, Liu YG, Hyde KD (2019b) Introducing Arthrinium phyllostachium sp. nov. (Apiosporaceae, Xylariales) on Phyllostachys heteroclada from Sichuan Province, China. Phytotaxa 406(2): 91-110. https://doi.org/10.11646/phytotaxa.406.2.2

Yang CL, Xu XL, Liu YG (2019c) Two new species of Bambusicola (Bambusicolaceae, Pleosporales) on Phyllostachys heteroclada from Sichuan, China. Nova Hedwigia 108(3): 527-545. https://doi.org/10.1127/nova_hedwigia/2019/0526

Yang CL, Xu XL, Liu YG, Hyde KD, McKenzie EHC (2019d) A new species of Phyllachora (Phyllachoraceae, Phyllachorales) on Phyllostachys heteroclada from Sichuan, China. Phytotaxa 392(3): 186-196. https://doi.org/10.11646/phytotaxa.392.3.2 
Yang CL, Xu XL, Liu YG (2019e) Podonectria sichuanensis, a potentially mycopathogenic fungus from Sichuan Province in China. Phytotaxa 402(5): 219-231. https://doi.org/10.11646/ phytotaxa.402.5.1

Yang CL, Xu XL, Wanasinghe DN, Jeewon R, Phookamsak R, Liu YG, Liu LJ, Hyde KD (2019f) Neostagonosporella sichuanensis gen. et sp. nov. (Phaeosphaeriaceae, Pleosporales) on Phyllostachys heteroclada (Poaceae) from Sichuan Province, China. MycoKeys 46: 119150. https://doi.org/10.3897/mycokeys.46.32458

Yi TP (1997) Bamboos Flora of Sichuan. China Forestry Publishing House, 358 pp.

Yi TP, Shi JY, Ma LS, Wang HT, Yang L (2008) Iconographia Bambusoidearum Sinicarum. Science Press, 766 pp.

Zhou DQ, Hyde KD, Wu XL (2001) New records of Ellisembia, Penzigomyces, Sporidesmium and Repetophragma species on Bamboo from China. Acta Botanica Yunnanica 23(1): 45-51.

\section{Supplementary material I}

\section{Figure S1}

Authors: Xiu-Lan Xu, Chun-Lin Yang, Rajesh Jeewon, Dhanushka N. Wanasinghe, Ying-Gao Liu, Qian-Gang Xiao

Data type: multimedia

Copyright notice: This dataset is made available under the Open Database License (http://opendatacommons.org/licenses/odbl/1.0/). The Open Database License $(\mathrm{ODbL})$ is a license agreement intended to allow users to freely share, modify, and use this Dataset while maintaining this same freedom for others, provided that the original source and author(s) are credited.

Link: https://doi.org/10.3897/mycokeys.70.54231.suppl1

\section{Supplementary material 2}

\section{Figure S2}

Authors: Xiu-Lan Xu, Chun-Lin Yang, Rajesh Jeewon, Dhanushka N. Wanasinghe, Ying-Gao Liu, Qian-Gang Xiao

Data type: multimedia

Copyright notice: This dataset is made available under the Open Database License (http://opendatacommons.org/licenses/odbl/1.0/). The Open Database License $(\mathrm{ODbL})$ is a license agreement intended to allow users to freely share, modify, and use this Dataset while maintaining this same freedom for others, provided that the original source and author(s) are credited.

Link: https://doi.org/10.3897/mycokeys.70.54231.suppl2 